\title{
Effect of wastewater irrigation with zinc application on okra crop
}

Govind Kumar Maurya

Received : 13.11.2018; Revised : 01.02.2019; Accepted : 18.02 .2019

Author for Correspondence :

Govind Kumar Maurya Department of Soil and Water Engineering, Rajendra Agricultural University, Pusa, Samastipur (Bihar) India Email : govindmaurya548 @ gmail.com
- ABSTRACT : An investigation was carried out to evaluate the effect of wastewater irrigation and zinc combination on growth and yield of okra (Abelmoschus esculentus). The pot experiment was conducted for okra crop var. INDAM-9821 during Kharif season of the year 2011. The experiment was designed as per Factorial Completely Randomized Design (FCRD) with four irrigation treatments, four zinc treatments and three replications. The irrigation treatments consisted of all fresh water irrigation, two fresh and one sewage water irrigation, alternate fresh and sewage water irrigation and all sewage water irrigation. The zinc treatments consisted of application of $\mathrm{Zn} @ 0.0,2.5,5.0$ and $7.5 \mathrm{~kg} \mathrm{Zn} / \mathrm{ha}$. The study revealed that alternate irrigation with fresh water and wastewater along with the application of Zn @ $5.0 \mathrm{~kg} / \mathrm{ha}$ resulted in better crop growth, early flowering and highest yield of okra. The maximum concentration of $\mathrm{Zn}(51.50 \mathrm{mg} / \mathrm{kg}), \mathrm{Mn}(37.84 \mathrm{mg} / \mathrm{kg})$ were found in fruits under treatment alternate irrigation with application of $\mathrm{Zn} @ 5.0 \mathrm{~kg} / \mathrm{ha}$. The concentration of Fe in okra fruits maximum $(871.67 \mathrm{mg} / \mathrm{kg})$ in treatment all waste water irrigation with no application of zinc. Similarly, regarding the plant residue (dry matter) the highest concentrations of $\mathrm{Zn}(88.54 \mathrm{mg} / \mathrm{kg}), \mathrm{Mn}(59.56 \mathrm{mg} / \mathrm{kg})$ were also seen for treatment alternate irrigation with application of Zn @ $5.0 \mathrm{~kg} / \mathrm{ha}$, while maximum concentration of Fe $(1531.34 \mathrm{mg} / \mathrm{kg})$ was showed in alternate irrigation with no application of $\mathrm{Zn}$.

— KEY WORDS : Okra, Wastewater, Irrigation, Zinc

- HOW TO CITE THIS PAPER : Maurya, Govind Kumar (2019). Effect of wastewater irrigation with zinc application on okra crop. Internat. J. Agric. Engg., 12(1) : 1-9, DOI: 10.15740/HAS/ IJAE/12.1/1-9. Copyright@2019: Hind Agri-Horticultural Society. 